\title{
PENGEMBANGAN MEDIA PEMBELAJARAN INTERAKTIF MENGGUNAKAN SIMULASI ANIMASI PADA MATAKULIAH CHASIS OTOMOTIF
}

\author{
Andi Bahar ${ }^{1}$, Abdul Muin Sibuea ${ }^{2}$ \\ Fakltas Teknik, Teknologi Pendidikan Pascasarjana Universitas Negeri Medan \\ andi_bahar@yahoo.com ${ }^{1}$
}

\begin{abstract}
Abstrak: Tujuan penelitian ini adalah untuk menghasilkan media pembelajaran interaktif menggunakan simulasi animasi pada matakuliah chasis otomotif yang berkualitas, mudah dipelajari dan dipahami mahasiswa serta dapat digunakan untuk pembelajaran individual. Penelitian ini adalah penelitian pengembangan yang menggunakan model pengembangan produk Borg dan Gall yang dipadu dengan desain pengembangan pembelajaran Dick dan Carey. Hasil penelitian menunjukkan bahwa (1) Secara keseluruhan media pembelajaran interaktif yang dikembangkan layak untuk digunakan sebagai media pembelajaran pada matakuliah chasis otomotif untuk mahasiswa program studi Pendidikan Teknik Otomotif Jurusan Teknik Mesin Fakultas Teknik Universitas Negeri Medan dengan persentase rata-rata "sangat baik", (2) uji ahli materi matakuliah chasis otomotif berada pada kriteria sangat baik, (3) uji ahli desain pembelajaran berada pada kriteria sangat baik, (4) uji ahli media berada pada kriteria sangat baik, (5) uji coba perorangan termasuk pada kriteria sangat baik, (6) uji coba kelompok kecil berada pada kriteria sangat baik, dan (7) uji coba lapangan berada pada kriteria sangat baik.
\end{abstract}

\section{Kata Kunci: Media Pembelajaran, Interaktif, Simulasi Animasi, Chasis Otomotif}

Abstract: The purpose of this study is to produce an interactive learning media using animated simulation on course quality automotive chassis, easy to learn and understand the students and can be used for individual learning. This study is the development of the model Borg and Gall product development combined with the design of learning development Dick and Carey. The results showed that (1) Overall media interactive learning developed feasible for use as a medium of learning in the course of the chassis of automotive for students of Education of Automotive Engineering Department of Mechanical Engineering, Faculty of Engineering, State University of Medan with the average percentage of "very good", (2) test material experts courses chassis automotive are in very good criteria, (3) test expert instructional design that are in very good criteria, (4) test media experts are in very good criteria, (5) individual testing included in the criteria very well , (6) small group trial was on the criteria very well, and (7) are in the field trial criteria very well.

\section{Keywords: Learning Media, Interactive, Animation Simulation, Automotive Chassis}

\section{PENDAHULUAN}

Penggunaan media pembelajaran untuk matakuliah chasis otomotif menggunakan simulasi animasi sangat cocok untuk pembelajaran individual karena dapat digunakan secara interaktif oleh mahasiswa sebagai pebelajar. Penggunaan media ini tentunya memerlukan perangkat komputer dalam pengoperasiannya sebagai sarana yang baik dalam membantu proses pembelajaran. Hal ini dikarenakan komputer mempunyai berbagai kemampuan sebagai berikut: cepat, andal, dan tepat dalam komputasi, penyelesaian persamaan secara non analitis, simulasi dari proses-proses dan eksperimen, penyelesaian masalah secara grafis, program-program interaktif.

Pelaksanaan proses pembelajaran yang efektif sebaiknya tidak lagi memandang bahwa penggunaan media hanya sebagai alat bantu bagi dosen atau guru dalam mengajar, akan tetapi media sudah selayaknya dipandang sebagai alat penyalur pesan. Dalam hal-hal tertentu media pembelajaran interaktif dengan simulasi animasi pada matakuliah chasi otomotif ini dapat menjadi penyaji dan penyalur pesan dalam menyampaikan informasi secara lebih teliti, jelas, dan menarik tanpa kehadiran dosen. Media pembelajaran interaktif dengan simulasi animasi pada matakuliah chasis otomotif dapat 
digunakan baik oleh dosen, guru maupun mahasiswa.

Kemampuan berinteraksi dengan mahasiswa pada penggunaan media pembelajaran interaktif dengan simulasi animasi pada matakuliah chasis otomotif merupakan ciri yang paling menarik. Interaksi antara komputer dengan mahasiswa dilakukan secara individual, sehingga apa yang dialami oleh seorang mahasiswa akan berbeda dengan apa yang dialami oleh mahasiswa lain. Kondisi seperti ini memungkinkan interaksi dengan sejumlah besar mahasiswa dapat berlangsung pada saat yang sama, berbeda dengan interaksi antara dosen dan mahasiswa yang hanya terjadi secara bergantian sehingga memerlukan waktu lebih lama.

Pembelajaran adalah suatu kombinasi yang tersusun meliputi unsur-unsur manusiawi, fasilitas, perlengkapan, dan prosedur yang saling mempengaruhi untuk mencapai tujuan dari pembelajaran itu sendiri (Hamalik, 2003: 54). Menurut Degeng dalam Husamah \& Yanur (2013: 34), pembelajaran adalah upaya untuk membelajarkan siswa. Secara implisit dalam pembelajaran, terdapat kegiatan memilih, menetapkan, mengembangkan metode untuk mencapai hasil pengajaran yang diinginkan, serta didasarkan pada kondisi pembelajaran yang ada, kegiatan ini merupakan inti dari perencanaan pembelajaran.

Teknologi Pendidikan muncul sebagai upaya untuk memecahkan permasalahan dalam belajar. Dengan menerapkan teori dan praktik dari ilmu Teknologi Pendidikan dapat diatasi apa yang menjadi masalah dalam belajar. Assosiaciation of Educational Communications Technology (AECT) pada tahun 1977 mendefinisikan Teknologi Pendidikan sebagai berikut : "Educational Technology is a complex, integrated involving people, procedurs, ideas, devices, and organization for analyzing problem and deviciting, implementing, evaluating and managing solutions to those problem in volvesin all aspect of human learning". Definisi ini menjelaskan bahwa Teknologi Pendidikan adalah proses kompleks dan terpadu yang melibatkan orang-orang, prosedur, ide, peralatan, dan organisasi untuk menganalisis masalah, mencari jalan pemecahan, melaksanakan, mengevaluasi, mengelola pemecahan masalah yang menyangkut semua aspek belajar manusia (AECT, 1977 : 1).

Selain itu penggunaan istilah Teknologi Pendidikan sering dikacaukan dengan Teknologi Pembelajaran. Beberapa ahli mengatakan bahwa penggunaan istilah pembelajaran lebih sempit daripada pendidikan. Terlepas dari masalah penggunaan istilah, dari kata kedua istilah itu dianggap sinonim karena sama-sama mempermasalahkan tentang proses belajarmengajar dan sumber belajar. Dalam bukunya, Seels dan Richey menggunakan Teknologi Pembelajaran dalam definisi terbaru. Definisi tersebut tertulis "Instructional Technology is the theory and practice of design, development, utilization, management, and evaluation of processes and resources of learning" (Seels dan Richey, 1996: 1). Artinya Teknologi Pembelajaran adalah teori dan praktik yang merancang, mengelola, memanfaatkan, mengembangkan dan mengevaluasi proses dan sumber untuk belajar. Pengertian yang baru ini tidak hanya menitik beratkan pada kondisi praktis saja tetapi juga pada tataran konsep atau teori.

Chasis otomotif adalah bahasa universal dalam bidang otomotif, dimana chasis ini merupakan bagian bodi dan rangka dari sebuah kendaraan terutama pada kategori kendaraan ringan. Materi pelajaran otomotif secara garis besar dapat dibagi menjadi tiga bagian yakni; Engine otomotif, chasis otomotif, dan kelistrikan otomotif. Chasis otomotif selanjutnya dibagi lagi menjadi tiga bagian yakni chasis otomotif, pengecatan body, dan pemindah daya otomotif. Kawasan dari chasis otomotif adalah sistem rem, sistem kemudi, sistem suspensi/pemegasan, pengaturan posisi roda depan (wheel alignment), serta roda (Veleg serta ban), kawasan pengecatan body adalah pengecatan, perbaikan kaca, perbaikan pintu-pintu dan tempat duduk, sedangkan kawasan dari pemindah daya meliputi kopling, transmisi, poros profeller, dan diferensial, serta poros roda. Pemahaman terhadap komponen dan cara kerja dari sistem yang ada akan membantu mekanik dalam menganalisa kerusakan yang terjadi untuk menganbil keputusan apakah komponen atau sub komponen tersebut diperbaiki atau diganti. Oleh sebab itu, mata kuliah ini akan membantu untuk memperoleh kemampuan dalam mengenal dan memahami proses kerja sesuai dengan standard yang ada, serta memiliki kemampuan menganalisis kerusakan yang terjadi.

Sistem yang ada pada chasis otomotif ini dimaksudkan untuk memberikan kenyamanan dan keamanan bagi pengendara saat menjalankan kendaraan. Dengan demikian pada bagian chasis ini senantiasa berkembang sesuai dengan tuntutan kebutuhan. Sekaitan dengan 
pengembangan komponen sistem untuk memperoleh kenyamanan dan keamanan tentunya mengikuti prosedur pengembangan produk atau produk baru tetap mengikuti lima tahap berikut ini: (1) Pengenalan permasalahan, (2) Konsep-konsep dan ide-ide, (3) Pemecahan masalah disetujui bersama, (4) Model atau protipe, dan (5) produksi atau gambar-gambar kerja.

Pengembangan media pembelajaran chasis otomotif dengan intekraksi animasi, proses pembelajarannya menggunakan media komputer. Menurut Heinich, et.al. (1996:16) pembelajaran yang menggunakan media dapat ditinjau dengan lima perspektif pada teori pembelajaran yaitu behaviorisme, kognitivisme, konstruktrivisme, dan psikologi sosial, serta teori pemrosesan informasi.

Teori belajar behavioristik merupakan teori yang banyak berpengaruh dalam perkembangan teknologi pembelajaran seperti yang dikemukakan Heinich, et.al (1996:16) adalah teori kondisioning operan oleh Skinner dengan konsep stimulus respon dan faktor penguatan. Beberapa program yang banyak dipakai dalam teorinya Skinner diantaranya teaching machine dan pembelajaran terprogram yang merupakan cikal bakal pembelajaran menggunakan simulasi animasi.

Teori belajar kognitif digunakan untuk menyelesaikan problem-problem belajar yang kompleks. Teori belajar kognitif yang sering digunakan adalah Teori Perkembangan Mental Piaget, seperti yang dikemukakan oleh Heinich, et.al. (1996:17), dalam belajar akan ada proses secara tertutup dalam penerimaan materi ke otak sesuai dengan kemampuan mahasiswa. Model tutorial dianggap sesuai dengan perkembangan teori kognitif Piaget. Teori belajar kognitif lainnya adalah Teori Belajar Ausubel (Degeng: 1989). Dalam teori Ausubel ini struktur organisasional yang ada dalam ingatan seseorang dapat diintegrasikan unsur-unsur berpisah ke dalam suatu unit konseptual, yang berarti akan semakna dengan fungsi pengembangan media interaktif dengan simulasi animasi pada matakuliah chasis otomotif itu sendiri. Teori belajar Ausubel merupakan teori belajar konsep sedangkan gambar teknik mempelajari konsep-konsep chasis otomotif sehingga ada kesesuaian. Konsep belajar chasis otomotif selalu dipelajari dari konsep dasar terlebih dahulu menuju konsep yang lebih sulit.

\begin{tabular}{ccc} 
Teori & belajar & \multicolumn{2}{c}{ konstrukrivistik } \\
menjelaskan & bahwa & dengan dasar
\end{tabular}

konstruktivisme pembelajaran harus dikemas menjadi proses mengkonstruksi bukan menerima pengetahuan. Heinich et.al. (1996:17) mengemukakan bahwa teori belajar konstruktivisme merupakan teori belajar yang menekankan pada pengalaman mahasiswa, tidak semata pengetahuan kognitif. Menurut teori konstruktivisme mahasiswa membangun sendiri pengetahuannya melalui keterlibatannya secara aktif dalam proses pembelajaran. Selain itu konstruktivisme membantu mahasiswa menginternalisasi dan mentransformasi informasi baru pada pembelajaran gambar teknik dengan teori konstruktivisme ini diharapkan akan mampu mengkonstruksi pengetahuan mahasiswa dengan berbagai model pembelajaran.

Salah satu faktor yang mempengaruhi dan berperan penting dalam pembentukan pribadi dan perilaku individu adalah belajar. Penafsiran kata belajar berbeda-beda oleh banyak pakar pendidikan di Indonesia. Menurut Slameto (2003:2) menjelaskan bahwa "belajar adalah proses usaha yang dilakukan seseorang untuk memperoleh suatu perubahan tingkah laku yang baru secara keseluruhan sebagai pengalamannya sendiri dalam interaksi dengan lingkungannya".

Prestasi belajar menurut Gagne dan Briggs (1979:52), “dapat dikelompokkan ke dalam 5 (lima) kategori yaitu : 1) keterampilan intelektual, 2) informasi verbal, 3) strategi kognitif, 4) keterampilan motorik, dan 5) sikap. Pendapat ini diartikan : Pertama, keterampilan intelektual (intellectual skills). Belajar keterampilan intelektual berarti belajar bagaimana melakukan sesuatu secara intelektual. Ada enam jenis keterampilan intelektual, : (1) diskriminasi-diskriminasi, yaitu kemampuan membuat respons yang berbeda terhadap stimulus yang berbeda pula; (2) konsep-konsep konkret, yaitu kemampuan mengidentifikasi ciri-ciri atau atribut-atribut suatu objek; (3) konsep-konsep terdefinisi, yaitu kemampuan memberikan makna terhadap sekelompok objek-objek, kejadian-kejadian, atau hubungan-hubungan; (4) aturan-aturan, yaitu kemampuan merespons hubunganhubungan antara objek-objek dan kejadiankejadian; (5) aturan tingkat tinggi, yaitu kemampuan merespons hubungan-hubungan antara objek-objek dan kejadian-kejadian secara lebih kompleks; (6) memecahkan masalah, yaitu kemampuan memecahkan masalah yang biasanya melibatkan aturan-aturan tingkat 
tinggi. Kedua, strategi-strategi kognitif (cognitive strategies). Strategi-strategi ini merupakan kemampuan yang mengarahkan prilaku belajar, mengingat, dan berpikir seseorang. Ada lima jenis strategi-strategi kognitif : (1) strategi-strategi menghafal, yaitu strategi belajar yang dilakukan dengan cara menghafal ide-ide dari sebuah teks; (2) strategistrategi elaborasi, yaitu strategi belajar dengan cara mengaitkan materi yang dipelajari dengan materi lain yang relevan; (3) strategi-strategi pengaturan, yaitu strategi belajar yang dilakukan dengan cara mengelompokkan konsep-konsep agar menjadi kategori-kategori yang bermakna; (4) strategi-strategi pemantauan pemahaman, yaitu strategis belajar yang dilakukan dengan cara memantau proses-proses belajar yang sedang dilakukan; (5) strategi -strategi afektif, yaitu strategi belajar yang dilakukan dengan cara memusatkan dan mempertahankan perhatian. Ketiga, informasi verbal (verbal information). Belajar informasi verbal adalah belajar untuk mengetahui apa yang dipelajari baik yang berbentuk nama-nama objek, fakta-fakta, maupun pengetahuan yang telah disusun dengan baik. Keempat, keterampilan motor (motor skills). Kemahiran ini merupakan kemampuan siswa untuk melakukan sesuatu dengan menggunakan mekanisme otot yang dimiliki. Kelima, sikap (attitudes). Sikap merupakan kemampuan mereaksi secara positif atau negatif terhadap orang, sesuatu, dan situasi.

Menurut Seels dan Richey (1994: 41) pengertian pengembangan adalah proses penerjemahan spesifikasi desain ke dalam bentuk fisiknya. Pengertian tersebut menunjukkan pengembangan merupakan implikasi fungsi teknologi pembelajaran untuk memcahkan masalah belajar dan pembelajaran yang menyangkut segala macam sumber belajar yang berupa pesan orang, bahan, alat, teknik dan lingkungan baik yang digunakan sendiri-sendiri secara gabungan untuk mempermudah proses pembelajaran.

Menurut Atwi Suparman (2001: 30)

pengembangan pembelajaran lebih menitikberatkan pada tujuannya yaitu memecahkan masalah belajar, meningkatkan kualitas kegiatan pembelajaran, atau menciptakan situasi kondisi belajar yang memungkinkan mahasiswa berinteraksi sehingga terjadi perubahan perilaku melalui suatu proses yang meliputi desain, produksi, dan evaluasi. Prosesnya dimulai dengan mengidentifikasi masalah, mengembangkan strategi dan bahan pembelajaran diakhiri dengan mengevaluasi efektivitas dan efisiensi.

Proses pencapaian kompetensi dasar dikembangkan melalui pemilihan strategi pembelajaran, yang meliputi pembelajaran tatap muka dan pengalaman belajar. Pengalaman belajar merupakan kegiatan fisik maupun mental yang dilakukan mahasiswa dalam berinteraksi dengan bahan belajar melalui pembelajaran yang dilakukan di dalam maupun di luar kelas dengan metode yang bervariasi. Menurut Dick \& Carey (2005: 190) strategi pembelajaran terdiri dari lima langkah yaitu: (1) aktivitas sebelum pembelajaran, (2) presentasi informasi, (3) partisipasi mahasiswa, (4) pengujian, dan (5) aktivitas lanjutan. Pemilihan strategi harus memperhatikan karakteristik dan tuntutan perkembangan matakuliah yaitu dosen harus: (1) menciptakan kemerdekaan untuk mengekspresikan ide-ide, (2) menyediakan lingkungan yang responsif, agar setiap mahasiswa dapat memperoleh data yang diinginkan dan (3) membantu mahasiswa menemukan suatu pengarahan untuk bergerak maju. Dalam menjelaskan dan menggunakan prinsip pengajaran berprogram dengan memberikan layanan perbedaan individual. Untuk efektivitas dan efisiensi pembelajaran berbasis komputer pemilihan strategi memperhatikan faktor belajar, yaitu stimulus, response, dan feedback.

Salah satu sistem pembelajaran yang sesuai dengan pembelajaran individual adalah pembelajaran dengan modul seperti yang dikemukakan oleh Kemp (1994: 147). Istilah modul pada awalnya merupakan istilah dalam bidang teknik yang diambil oleh dunia pendidikan untuk menunjukkan suatu konsep baru tentang unit program pembelajaran. Menurut Russel (1973: 13), sumber belajar yang berupa pembelajaran mandiri mempunyai ciriciri umum, yaitu: (1) self- contained, self instroduction packase, (2) concern for individual differencesof knowledge, (3) statement of objectives, (4) assosiation, structure and sequnce of knowledge, (5) utilization of varieties of media, (6) active partisipation by the leaner, (7) immediate reinforcement of responses, (8) mastery evaluation stategy.

Azhar Arsyad (1997: 32-33) mengemukakan fungsi utama penggunaan komputer dalam pembelajaran adalah dapat digunakan : (1) secara acak, sekuensial, secara linear, (2) sesuai dengan keinginan mahasiswa, bukan saja dengan cara yang direncanakan dan 
diinginkan oleh perancangnya, (3) gagasangagasan sering disajikan secara komputer dalam kontek pengalaman mahasiswa menurut apa yang relevan dengan mahasiswa dan di bawah pengendalian mahasiswa, (4) prinsip ilmu kognitif dan konstruktivisme diterapkan dalam lingkup kognitif sehingga pengetahuan dikuasai jika pelajaran itu digunakan, (6) bahan-bahan pelajaran melibatkan banyak interaktivitas mahasiswa, (7) bahan-bahan pelajaran memadukan kata dan visual dari berbagai sumber.

\section{METODE}

Penelitian ini dilaksanakan di Prodi Pendidikan Teknik Otomotif Jurusan Teknik Mesin Fakultas Teknik Unimed. Metode penelitian yang digunakan adalah research and development, karena penelitian ini termasuk penelitian pengembangan pendidikan yang dimaksudkan untuk menghasilkan produk pembelajaran yang layak dimanfaatkan dan sesuai kebutuhan. Borg dan Gall (1983) memberikan batasan tentang penelitian pengembangan sebagai usaha untuk mengembangkan dan memvalidasi produkproduk yang digunakan dalam pendidikan. Pengertian yang hampir sama dikemukakan oleh Asim (Waldopo, 2002: 1) bahwa penelitian pengembangan dalam pembelajaran adalah proses yang digunakan untuk mengembangkan dan memvalidasi produk-produk yang digunakan dalam proses pembelajaran.

Skema model pengembangan tersebut dapat digambarkan sebagai berikut:

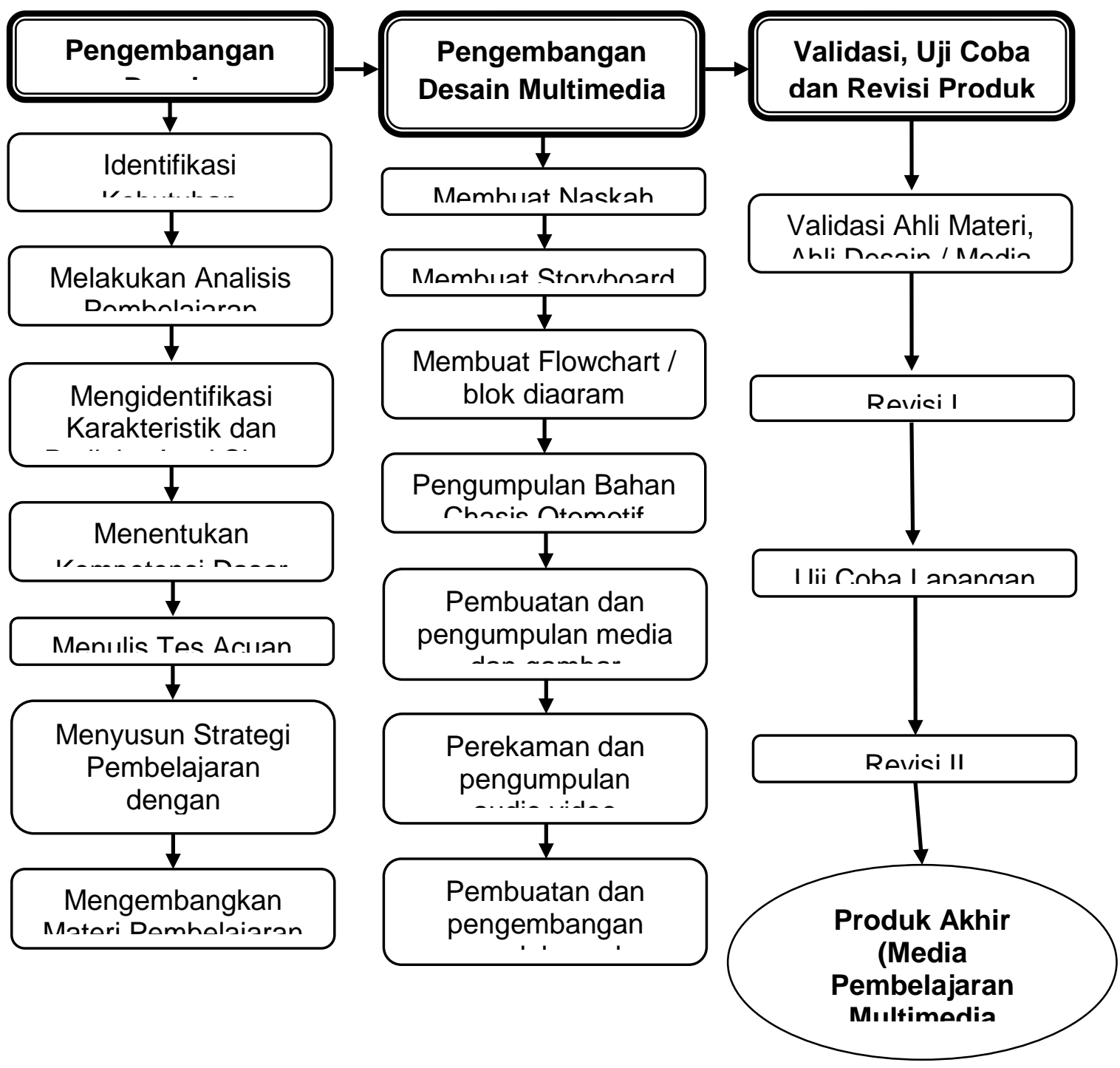

Gambar 1. Skema Model Pengembangan Multimedia Interaktif Pembelajaran 
Prosedur pengembangan yang ditempuh untuk menghasilkan produk pembelajaran interaktif menggunakan simulasi animasi akan dibagi menjadi 5 tahap (Borg dan Gall (1983)), yaitu : (a) tahap pertama melakukan penelitian pendahuluan, tahap ini diawali dengan identifikasi kebutuhan pembelajaran dan menentukan standar kompetensi mata kuliah, melakukan analisis pembelajaran, mengidentifikasi karakteristik dan perilaku awal mahasiswa, menentukan kompetensi dasar serta indikator, menulis tes acuan patokan, mengembangkan materi pembelajaran, (b) tahap kedua pembuatan desain media, Pada tahap ke dua ini diawali dengan pembuatan desain software, Pembuatan Naskah, Pembuatan Storyboard, Pembuatan Flowchart view, (c) tahap ketiga pengumpulan bahan, diawali dengan pengumpulan bahan, pembuatan dan pengumpulan gambar animasi, perekaman dan pengumpulan audisi, (d) tahap keempat membuat dan memproduksi media pembelajaran interaktif menggunakan animasi, yang dilengkapi dengan petunjuk-petunjuk media seperti: petunjuk belajar, deskripsi singkat, kompetensi dasar, uraian materi, soal-soal latihan dan balikan, yang terakhir sebagai penutup adalah rangkuman, (e) tahap kelima yaitu review atau uji lapangan dalam rangka revisi produk.

Analisis data dalam penelitian ini menggunakan analisis deskriptif kuantitatif.
Semua data yang terkumpul dianalisis dengan teknik statistik deskriptif yang secara kuantitatif dipisahkan menurut kategori untuk mempertajam penilaian dalam menarik kesimpulan. Data kualitatif yang berupa pernyataan sangat kurang, kurang baik, sedang, baik, dan sangat baik diubah menjadi data kuantitatif dengan skala nilai 1 sampai 5 . Hasilnya dirata-rata dan digunakan untuk menilai kualitas media pembelajaran. Kriteria media pembelajaran akan dikonversikan menjadi nilai dengan skala lima menggunakan Skala Likert yang dianalisis secara deskriptif persentase dengan rumus sebagai berikut :

$$
x=
$$

$$
\frac{\text { Jumlah Skor Yang Diperoleh }}{\text { Jumlah Skor Ideal Seluruh Item }} \times 100 \%
$$

(Sugiyono, 2007)

Dengan kriteria penilaian seperti yang tertulis pada tabel 4 berikut ini.

Tabel 1 . Kriteria Penilaian

\begin{tabular}{|c|c|c|}
\hline Nilai & Kriteria & Persentase \\
\hline 5 & Sangat Baik & $81 \% \leq \mathrm{X} \leq 100 \%$ \\
\hline 4 & Baik & $61 \% \leq \mathrm{X} \leq 80 \%$ \\
\hline 3 & Sedang & $41 \% \leq \mathrm{X} \leq 60 \%$ \\
\hline 2 & Kurang Baik & $21 \% \leq \mathrm{X} \leq 40 \%$ \\
\hline 1 & Sangat Kurang & $0 \% \leq \mathrm{X} \leq 20 \%$ \\
\hline
\end{tabular}

$\mathrm{X}=$ Skor Empiris

\section{HASIL DAN PEMBAHASAN \\ Hasil}

Tabel 2. Skor Penilaian Media Pembelajaran Interaktif Oleh Ahli Materi Tentang Kualitas

\begin{tabular}{|c|c|c|c|c|c|c|}
\hline \multirow[t]{2}{*}{ No. } & \multirow[t]{2}{*}{ Indikator Penilaian } & \multicolumn{2}{|c|}{$\begin{array}{c}\text { Responde } \\
n\end{array}$} & \multirow{2}{*}{$\begin{array}{c}\text { Jumlah } \\
\text { Skor }\end{array}$} & \multirow{2}{*}{$\begin{array}{c}\text { Rata-Rata } \\
(\%)\end{array}$} & \multirow[t]{2}{*}{ Kriteria } \\
\hline & & 1 & 2 & & & \\
\hline 1 & Kejelasan tujuan pembelajaran & 5 & 5 & 10 & $100 \%$ & Sangat Baik \\
\hline 2 & Ketepatan cakupan materi & 5 & 5 & 10 & $100 \%$ & Sangat Baik \\
\hline 3 & Kualitas soal-soal latihan & 5 & 5 & 10 & $100 \%$ & Sangat Baik \\
\hline 4 & $\begin{array}{l}\text { Ketercernaan materi dan kelogisan } \\
\text { pemaparan }\end{array}$ & 5 & 5 & 10 & $100 \%$ & Sangat Baik \\
\hline 5 & Penggunaan bahasa & 5 & 5 & 10 & $100 \%$ & Sangat Baik \\
\hline 6 & Kemudahan pemahaman bahasa & 4 & 5 & 9 & $90 \%$ & Sangat Baik \\
\hline 7 & Perwajahan & 5 & 4 & 9 & $90 \%$ & Sangat Baik \\
\hline 8 & Ilustrasi & 4 & 4 & 8 & $80 \%$ & Baik \\
\hline \multicolumn{4}{|c|}{ Rata-Rata } & 9.5 & $95 \%$ & Sangat Baik \\
\hline
\end{tabular}
Materi Pembelajaran

Tabel 2. Skor Penilaian Media Pembelajaran Interaktif Oleh Ahli Materi Tentang Kualitas Strategi Pembelajaran (Skala 1 - 5)

\begin{tabular}{|l|l|c|c|c|c|c|}
\hline \multirow{2}{*}{ No. } & Indikator Penilaian & \multicolumn{2}{|c|}{ Responden } & Jumlah & Rata-Rata & \multirow{2}{*}{ Kriteria } \\
\cline { 3 - 4 } & & 1 & 2 & Skor & $(\%)$ & \\
\hline 1 & Kualitas pendahuluan & 4 & 5 & 9 & $90 \%$ & Sangat Baik \\
\hline
\end{tabular}




\begin{tabular}{|l|l|c|c|c|c|l|}
\hline 2 & Kualitas penyajian materi & 5 & 5 & 10 & $100 \%$ & Sangat Baik \\
\hline 3 & $\begin{array}{l}\text { Keterlibatan dan peran peserta } \\
\text { didik dalam aktivitas belajar }\end{array}$ & 5 & 4 & 9 & $90 \%$ & Sangat Baik \\
\hline 4 & Kualitas umpan balik & 5 & 5 & 10 & $100 \%$ & Sangat Baik \\
\hline 5 & Waktu penyajian & 4 & 4 & 8 & $80 \%$ & Baik \\
\hline \multicolumn{2}{|c|}{ Rata-Rata } & & $\mathbf{9 . 2}$ & $\mathbf{9 2 \%}$ & Sangat Baik \\
\hline
\end{tabular}

Tabel 3. Skor Penilaian Media Pembelajaran Interaktif Oleh Ahli Materi Tentang Kualitas Sistem Penyampaian Pembelajaran (Skala 1 - 5)

\begin{tabular}{|c|c|c|c|c|c|c|}
\hline \multirow{2}{*}{ No. } & \multirow{2}{*}{ Indikator Penilaian } & \multicolumn{2}{|c|}{ Responden } & \multirow{2}{*}{$\begin{array}{l}\text { Jumlah } \\
\text { Skor }\end{array}$} & \multirow{2}{*}{$\begin{array}{l}\text { Rata-Rata } \\
(\%)\end{array}$} & \multirow{2}{*}{ Kriteria } \\
\hline & & 1 & 2 & & & \\
\hline 1 & Kebenaran konsep & 4 & 4 & 8 & $80 \%$ & Baik \\
\hline 2 & $\begin{array}{l}\text { Kedalaman materi } \\
\text { pembelajaran }\end{array}$ & 5 & 5 & 10 & $100 \%$ & Sangat Baik \\
\hline 3 & Kesesuaian dengan kurikulum & 5 & 4 & 9 & $90 \%$ & Sangat Baik \\
\hline 4 & $\begin{array}{l}\text { Ketepatan urutan materi } \\
\text { pembelajaran }\end{array}$ & 4 & 5 & 9 & $90 \%$ & Sangat Baik \\
\hline \multicolumn{4}{|c|}{ Rata-Rata } & 9.0 & $90 \%$ & Sangat Baik \\
\hline
\end{tabular}

Tabel 4. Skor Penilaian Media Pembelajaran Interaktif Oleh Ahli Desain Pembelajaran Tentang Kualitas Desain Pembelajaran (Skala 1 - 5)

\begin{tabular}{|c|c|c|c|c|c|c|}
\hline \multirow{2}{*}{ No. } & \multirow{2}{*}{ Indikator Penilaian } & \multicolumn{2}{|c|}{ Responden } & \multirow{2}{*}{$\begin{array}{c}\text { Jumlah } \\
\text { Skor }\end{array}$} & \multirow{2}{*}{$\begin{array}{l}\text { Rata-Rata } \\
(\%)\end{array}$} & \multirow{2}{*}{ Kriteria } \\
\hline & & 1 & 2 & & & \\
\hline 1 & Ketepatan pemilihan topik & 4 & 5 & 9 & $90 \%$ & Sangat Baik \\
\hline 2 & $\begin{array}{l}\text { Kesesuaian materi dengan } \\
\text { indikator pembelajaran }\end{array}$ & 5 & 4 & 9 & $90 \%$ & Sangat Baik \\
\hline 3 & Pemberian latihan & 4 & 4 & 8 & $80 \%$ & Baik \\
\hline 4 & $\begin{array}{l}\text { Konsistensi tes dengan } \\
\text { indikator pembelajaran }\end{array}$ & 5 & 4 & 9 & $90 \%$ & Sangat Baik \\
\hline \multicolumn{4}{|c|}{ Rata-Rata } & 8.75 & $87,5 \%$ & Sangat Baik \\
\hline
\end{tabular}

Tabel 5. Skor Penilaian Media Pembelajaran Interaktif Oleh Ahli Desain Pembelajaran Tentang Kualitas Desain Informasi (Skala 1 - 5)

\begin{tabular}{|c|c|c|c|c|c|c|}
\hline \multirow[b]{2}{*}{ No. } & \multirow{2}{*}{ Indikator Penilaian } & \multicolumn{2}{|c|}{ Responden } & \multirow{2}{*}{$\begin{array}{l}\text { Jumlah } \\
\text { Skor }\end{array}$} & \multirow{2}{*}{$\begin{array}{c}\text { Rata-Rata } \\
(\%)\end{array}$} & \multirow{2}{*}{ Kriteria } \\
\hline & & 1 & 2 & & & \\
\hline 1 & Pemberian motivasi & 4 & 5 & 9 & $90 \%$ & Sangat Baik \\
\hline 2 & Kejelasan uraian materi & 5 & 4 & 9 & $90 \%$ & Sangat Baik \\
\hline 3 & $\begin{array}{l}\text { Kejelasan contoh yang } \\
\text { diberikan }\end{array}$ & 5 & 4 & 9 & $90 \%$ & Sangat Baik \\
\hline 4 & Penggunaan informasi baru & 4 & 5 & 9 & $90 \%$ & Sangat Baik \\
\hline 5 & $\begin{array}{l}\text { Umpan balik terhadap hasil } \\
\text { tes mahasiswa }\end{array}$ & 4 & 4 & 8 & $80 \%$ & Baik \\
\hline 6 & Pembabakan/sekuensial & 4 & 4 & 8 & $80 \%$ & Baik \\
\hline 7 & $\begin{array}{l}\text { Pemaksimalan proses } \\
\text { pembelajaran }\end{array}$ & 5 & 4 & 9 & $90 \%$ & Sangat Baik \\
\hline 8 & Kemudahan penggunaan & 5 & 5 & 10 & $100 \%$ & Sangat Baik \\
\hline \multicolumn{4}{|c|}{ Rata-Rata } & 8.88 & $\mathbf{8 8 , 8} \%$ & Sangat Baik \\
\hline
\end{tabular}

Tabel 6. Skor Penilaian Media Pembelajaran Interaktif Oleh Ahli Desain Pembelajaran Tentang Kualitas Interaksi (Skala 1 - 5)

\begin{tabular}{|l|c|c|c|c|c|c|}
\hline \multirow{2}{*}{ No. } & \multirow{2}{*}{ Indikator Penilaian } & \multicolumn{2}{|c|}{ Responden } & Jumlah & Rata-Rata & \multirow{2}{*}{ Kriteria } \\
\cline { 3 - 4 } & & 1 & 2 & Skor & $(\%)$ & \\
\hline 1 & Penggunaan petunjuk belajar & 5 & 4 & 9 & $90 \%$ & Sangat Baik \\
\hline
\end{tabular}




\begin{tabular}{|l|l|c|c|c|c|l|}
\hline 2 & Penjelasan istilah & 5 & 5 & 10 & $100 \%$ & Sangat Baik \\
\hline 3 & $\begin{array}{l}\text { Umpan balik terhadap } \\
\text { respon mahasiswa }\end{array}$ & 4 & 4 & 8 & $80 \%$ & Baik \\
\hline 4 & $\begin{array}{l}\text { Penggunaan teks yang } \\
\text { berbeda untuk menandai } \\
\text { bagian yang penting }\end{array}$ & 4 & 5 & 9 & $90 \%$ & Sangat Baik \\
\hline \multicolumn{2}{|c|}{ Rata-Rata } & & $\mathbf{9 . 0}$ & $\mathbf{9 0 \%}$ & Sangat Baik \\
\hline
\end{tabular}

Tabel 7. Skor Penilaian Media Pembelajaran Interaktif Oleh Ahli Desain Pembelajaran Tentang Kualitas Presentasi (Skala 1 - 5)

\begin{tabular}{|c|c|c|c|c|c|c|}
\hline \multirow{2}{*}{ No. } & \multirow{2}{*}{ Indikator Penilaian } & \multicolumn{2}{|c|}{ Responden } & \multirow{2}{*}{$\begin{array}{c}\text { Jumlah } \\
\text { Skor }\end{array}$} & \multirow{2}{*}{$\begin{array}{c}\text { Rata-Rata } \\
(\%)\end{array}$} & \multirow{2}{*}{ Kriteria } \\
\hline & & 1 & 2 & & & \\
\hline 1 & Komposisi warna & 3 & 4 & 7 & $70 \%$ & Baik \\
\hline 2 & Penggunaan grafis & 5 & 4 & 9 & $90 \%$ & Sangat Baik \\
\hline 3 & $\begin{array}{l}\text { Pemilihan jenis dan ukuran } \\
\text { font. }\end{array}$ & 4 & 3 & 7 & $70 \%$ & Baik \\
\hline 4 & Penggunaan tombol navigasi & 4 & 5 & 9 & $90 \%$ & Sangat Baik \\
\hline 5 & $\begin{array}{l}\text { Kualitas gambar dan } \\
\text { animasi }\end{array}$ & 4 & 5 & 9 & $90 \%$ & Sangat Baik \\
\hline 6 & Penggunaan musik & 5 & 4 & 9 & $90 \%$ & Sangat Baik \\
\hline & Rata-Rata & & & 8.33 & $83,3 \%$ & Sangat Baik \\
\hline
\end{tabular}

Tabel 8. Skor Penilaian Media Pembelajaran Interaktif Oleh Ahli Media Tentang Kualitas pemrograman (Skala 1 - 5)

\begin{tabular}{|c|c|c|c|c|c|c|}
\hline \multirow{2}{*}{ No. } & \multirow{2}{*}{ Indikator Penilaian } & \multicolumn{2}{|c|}{ Responden } & \multirow{2}{*}{$\begin{array}{c}\text { Jumlah } \\
\text { Skor }\end{array}$} & \multirow{2}{*}{$\begin{array}{l}\text { Rata-Rata } \\
(\%)\end{array}$} & \multirow{2}{*}{ Kriteria } \\
\hline & & 1 & 2 & & & \\
\hline 1 & Perintah Eksekusi & 5 & 5 & 10 & $100 \%$ & Sangat Baik \\
\hline 2 & $\begin{array}{l}\text { Konsistensi dengan alur } \\
\text { program }\end{array}$ & 4 & 5 & 9 & $90 \%$ & Sangat Baik \\
\hline 3 & Keberlanjutan Program & 5 & 4 & 9 & $90 \%$ & Sangat Baik \\
\hline 4 & Efisiensi Sistem & 5 & 5 & 10 & $100 \%$ & Sangat Baik \\
\hline 5 & Ketepatan Display & 4 & 5 & 9 & $90 \%$ & Sangat Baik \\
\hline 6 & Pengelolaan Disc & 4 & 5 & 9 & $90 \%$ & Sangat Baik \\
\hline 7 & $\begin{array}{l}\text { Konsistensi antar bagian } \\
\text { Pelajaran }\end{array}$ & 5 & 4 & 9 & $90 \%$ & Sangat Baik \\
\hline 8 & Kemudahan Modifikasi & 4 & 4 & 8 & $80 \%$ & Baik \\
\hline \multicolumn{2}{|r|}{ Rata-Rata } & & & 9.13 & $91,3 \%$ & Sangat Baik \\
\hline
\end{tabular}

Tabel 9. Skor Penilaian Media Pembelajaran Interaktif Oleh Ahli Media Tentang Kualitas Teknis atau Tampilan (Skala 1 - 5)

\begin{tabular}{|c|c|c|c|c|c|c|}
\hline \multirow{2}{*}{ No. } & \multirow{2}{*}{ Indikator Penilaian } & \multicolumn{2}{|c|}{ Responden } & \multirow{2}{*}{$\begin{array}{l}\text { Jumlah } \\
\text { Skor }\end{array}$} & \multirow{2}{*}{$\begin{array}{c}\text { Rata-Rata } \\
(\%)\end{array}$} & \multirow{2}{*}{ Kriteria } \\
\hline & & 1 & 2 & & & \\
\hline 1 & Keindahan Tampilan Layar & 4 & 5 & 9 & $90 \%$ & Sangat Baik \\
\hline 2 & Keterbacaan Teks & 5 & 5 & 10 & $100 \%$ & Sangat Baik \\
\hline 3 & $\begin{array}{l}\text { Kualitas Gambar dan } \\
\text { Animasi }\end{array}$ & 5 & 4 & 9 & $90 \%$ & Sangat Baik \\
\hline 4 & Komposisi Warna & 4 & 4 & 8 & $80 \%$ & Baik \\
\hline 5 & Navigasi & 5 & 4 & 9 & $90 \%$ & Sangat Baik \\
\hline 6 & Daya Dukung Musik & 4 & 5 & 9 & $90 \%$ & Sangat Baik \\
\hline 7 & Interaksi & 5 & 4 & 9 & $90 \%$ & Sangat Baik \\
\hline & Rata-Rata & & & 9.2 & $92 \%$ & Sangat Baik \\
\hline
\end{tabular}


Tabel 10. Skor Penilaian Media Pembelajaran Interaktif Menggunakan Simulasi Animasi Pada Matakuliah Chasis Otomotif untuk Uji Coba Perorangan di Prodi P.Tek.Otomotif Jurusan Tek.Mesin FT Unimed Tentang Kualitas Materi Pembelajaran

\begin{tabular}{|c|c|c|c|c|c|c|c|}
\hline \multirow[b]{2}{*}{ No. } & \multirow[b]{2}{*}{ Indikator Penilaian } & \multicolumn{3}{|c|}{ Responden } & \multirow{2}{*}{$\begin{array}{l}\text { Jumlah } \\
\text { Skor }\end{array}$} & \multirow{2}{*}{$\begin{array}{l}\text { Rata-Rata } \\
(\%)\end{array}$} & \multirow{2}{*}{ Kreteria } \\
\hline & & 1 & 2 & 3 & & & \\
\hline 1 & Kesesuaian materi & 4 & 4 & 5 & 13 & $86.67 \%$ & Sangat Baik \\
\hline 2 & Kejelasan Petunjuk belajar & 5 & 5 & 5 & 15 & $100.00 \%$ & Sangat Baik \\
\hline 3 & $\begin{array}{l}\text { Kemudahan memahami } \\
\text { kalimat pada Teks }\end{array}$ & 4 & 5 & 4 & 13 & $86.67 \%$ & Sangat Baik \\
\hline 4 & $\begin{array}{l}\text { Kemudahan memahami } \\
\text { pembelajaran }\end{array}$ & 5 & 4 & 4 & 13 & $86.67 \%$ & Sangat Baik \\
\hline 5 & Ketepatan urutan penyajian & 5 & 4 & 5 & 14 & $93.33 \%$ & Sangat Baik \\
\hline 6 & Kecukupan Latihan & 4 & 5 & 4 & 13 & $86.67 \%$ & Sangat Baik \\
\hline 7 & Kejelasan Umpan Balik & 4 & 4 & 4 & 12 & $80.00 \%$ & Baik \\
\hline 8 & $\begin{array}{l}\text { Bantuan Belajar Dengan } \\
\text { Program }\end{array}$ & 4 & 5 & 5 & 14 & $93.33 \%$ & Sangat Baik \\
\hline \multicolumn{5}{|c|}{ Rata-Rata } & 13.38 & $89.17 \%$ & Sangat Baik \\
\hline
\end{tabular}

Tabel 11. Skor Penilaian Media Pembelajaran Interaktif Menggunakan Simulasi Animasi Pada Matakuliah Chasis Otomotif untuk Uji Coba Perorangan di Prodi P.Tek.Otomotif Jurusan

Tek.Mesin FT Unimed Tentang Kualitas Teknis atau Tampilan

\begin{tabular}{|c|l|c|c|c|c|c|l|}
\hline \multirow{2}{*}{ No. } & \multirow{2}{*}{ Indikator Penilaian } & \multicolumn{3}{|c|}{ Responden } & Jumlah & Rata-Rata & \multirow{2}{*}{ Kroteria } \\
\cline { 3 - 7 } & & 1 & 2 & 3 & Skor & $(\%)$ & \\
\hline 1 & Keindahan Tampilan Layar & 3 & 5 & 5 & 13 & $86.67 \%$ & Sangat Baik \\
\hline 2 & Keterbacaan Teks & 5 & 5 & 4 & 14 & $93.33 \%$ & Sangat Baik \\
\hline 3 & $\begin{array}{l}\text { Kualitas Gambar dan } \\
\text { Animasi }\end{array}$ & 5 & 5 & 5 & 15 & $100.00 \%$ & Sangat Baik \\
\hline 4 & Komposisi Warna & 5 & 4 & 4 & 13 & $86.67 \%$ & Sangat Baik \\
\hline 5 & Navigasi & 4 & 4 & 5 & 13 & $86.67 \%$ & Sangat Baik \\
\hline 6 & Daya Dukung Musik & 4 & 4 & 4 & 12 & $80.00 \%$ & Baik \\
\hline 7 & Interaksi & 4 & 5 & 4 & 13 & $86.67 \%$ & Sangat Baik \\
\hline \multicolumn{2}{r}{ Rata-Rata } & & & $\mathbf{1 3 . 2 9}$ & $\mathbf{8 8 . 5 7 \%}$ & Sangat Baik \\
\hline
\end{tabular}

Tabel 13. Persentase Rata-Rata Hasil Penilaian Terhadap Media Pembelajaran Interaktif Menggunakan Simulasi Animasi Pada Matakuliah Chasis Otomotif Oleh Ahli Materi

\begin{tabular}{|c|l|c|l|}
\hline No. & \multicolumn{1}{|c|}{ Indikator } & Persentase Rata-Rata & \multicolumn{1}{|c|}{ Kriteria } \\
\hline 1 & Aspek materi pembelajaran & $95 \%$ & Sangat Baik \\
\hline 2 & Aspek strategi pembelajaran & $92 \%$ & Sangat Baik \\
\hline 3 & Aspek sistem penyampaian pembelajaran & $90 \%$ & Sangat Baik \\
\hline \multicolumn{2}{|c|}{ Rata-Rata } & $\mathbf{9 2 . 3 3 \%}$ & Sangat Baik \\
\hline
\end{tabular}

Tabel 14. Persentase Rata-Rata Hasil Penilaian Terhadap Media Pembelajaran Interaktif Menggunakan Simulasi Animasi Pada Matakuliah Chasis Otomotif Oleh Ahli Desain Pembelajaran

\begin{tabular}{|c|l|c|l|}
\hline No. & \multicolumn{1}{|c|}{ Indikator } & Persentase Rata-Rata & \multicolumn{1}{c|}{ Kriteria } \\
\hline 1 & Kualitas desain pembelajaran & $87,5 \%$ & Sangat Baik \\
\hline 2 & Kualitas desain informasi & $88,8 \%$ & Sangat Baik \\
\hline 3 & Kualitas desain interaksi & $90,0 \%$ & Sangat Baik \\
\hline 4 & Kualitas desain presentasi & $83,3 \%$ & Sangat Baik \\
\hline \multicolumn{2}{|r|}{ Rata-Rata } & $\mathbf{8 7 , 4 \%}$ & Sangat Baik \\
\hline
\end{tabular}

Berdasarkan tanggapan ahli desain pembelajaran interaktif menggunakan simulasi pembelajaran, dinyatakan bahwa media animasi pada matakuliah chasis otomotif layak 
untuk uji coba lapangan dengan revisi sesuai saran yang dikemukakan, yaitu pada teks tombol navigasi font sizenya terlalu kecil. Komentar-komentar ahli desain pembelajaran yang dirangkum menunjukkan media pembelajaran interaktif menggunakan simulasi animasi pada matakuliah chasis otomotif dapat diterima dan secara umum sangat baik. Hasil analisa dari permasalahan yang dikemukakan oleh ahli desain pembelajaran diuraikan sebagai berikut: (1) Terdapat kesalahan konsep yakni chasis otomotif mahasiswa otomotif, sebaiknya diganti chasis otomotif (sistem kemudi); (2) Semua pemaparan materi sebaiknya diberi musik pengiring yang sama

Tabel 15. Persentase Rata-Rata Hasil Penilaian Terhadap Media Pembelajaran Interaktif Menggunakan Simulasi Animasi Pada Matakuliah Chasis Otomotif Oleh Ahli Media

\begin{tabular}{|c|l|c|l|}
\hline No. & Indikator & Persentase Rata-Rata & \multicolumn{1}{c|}{ Kriteria } \\
\hline 1 & Kualitas Pemrograman & $91,30 \%$ & Sangat Baik \\
\hline 2 & Kualitas Teknis/ Tampilan & $92,00 \%$ & Sangat Baik \\
\hline \multicolumn{2}{|c|}{ Rata-Rata } & $\mathbf{9 1 , 7 0 \%}$ & Sangat Baik \\
\hline
\end{tabular}

Tabel 16. Persentase Rata-Rata Hasil Penilaian Terhadap Media Pembelajaran Interaktif Menggunakan Simulasi Animasi Pada Matakuliah Chasis Otomotif Pada Uji Coba Perorangan

\begin{tabular}{|c|l|c|l|}
\hline No. & Indikator & Persentase Rata-Rata & \multicolumn{1}{|c|}{ Kriteria } \\
\hline 1 & Kualitas Aspek Materi Pembelajaran & $89,17 \%$ & Sangat Baik \\
\hline 2 & Kualitas Aspek Teknis/ Tampilan & $88,57 \%$ & Sangat Baik \\
\hline \multicolumn{2}{|c|}{ Rata-Rata } & $\mathbf{8 8 , 8 7 \%}$ & Sangat Baik \\
\hline
\end{tabular}

Tabel 17. Persentase Rata-Rata Hasil Penilaian Terhadap Media Pembelajaran Interaktif Menggunakan Simulasi Animasi Pada Matakuliah Chasis Otomotif Pada Uji Coba Kelompok Kecil

\begin{tabular}{|c|l|c|l|}
\hline No. & Indikator & Persentase Rata-Rata & \multicolumn{1}{c|}{ Kriteria } \\
\hline 1 & Kualitas Aspek Materi Pembelajaran & $90,28 \%$ & Sangat Baik \\
\hline 2 & Kualitas Aspek Teknis/ Tampilan & $90,48 \%$ & Sangat Baik \\
\hline \multicolumn{2}{|c|}{ Rata-Rata } & $\mathbf{9 0 , 3 8 \%}$ & Sangat Baik \\
\hline
\end{tabular}

Tabel 18. Persentase Rata-Rata Hasil Penilaian Terhadap Media Pembelajaran Interaktif Menggunakan Simulasi Animasi Pada Matakuliah Chasis Otomotif Pada Uji Coba Lapangan

\begin{tabular}{|c|l|c|c|}
\hline No. & Indikator & Persentase Rata-Rata & Kriteria \\
\hline 1 & Kualitas Aspek Materi Pembelajaran & $93,17 \%$ & Sangat Baik \\
\hline 2 & Kualitas Aspek Teknis/ Tampilan & $93,30 \%$ & Sangat Baik \\
\hline \multicolumn{2}{|c|}{ Rata-Rata } & $\mathbf{9 3 , 2 4 \%}$ & Sangat Baik \\
\hline
\end{tabular}

Tabel 19. Rangkuman Persentase Rata-Rata Hasil Penilaian Terhadap Media Pembelajaran Interaktif Menggunakan Simulasi Animasi Pada Matakuliah Chasis Otomotif

\begin{tabular}{|c|l|c|l|}
\hline No. & \multicolumn{1}{|c|}{ Indikator } & Persentase Rata-Rata & \multicolumn{1}{|c|}{ Kriteria } \\
\hline 1 & Ahli Materi & $92,33 \%$ & Sangat Baik \\
\hline 2 & Ahli Desain Pembelajaran & $87,40 \%$ & Sangat Baik \\
\hline 3 & Ahli Media & $91,70 \%$ & Sangat Baik \\
\hline 4 & Mahasiswa uji coba perorangan & $88,87 \%$ & Sangat Baik \\
\hline 5 & Mahasiswa uji coba kelompok kecil & $90,38 \%$ & Sangat Baik \\
\hline 6 & Mahasiswa uji coba lapangan & $93,24 \%$ & Sangat Baik \\
\hline \multicolumn{2}{|c|}{ Rata-Rata } & $\mathbf{9 0 , 6 5 \%}$ & Sangat Baik \\
\hline
\end{tabular}

\section{Pembahasan}

Media pembelajaran interaktif pada matakuliah chasis otomotif ini merupakan media yang memuat materi pembelajaran yang telah dikembangkan dengan memperhatikan aspek pembelajaran dan aspek media sebagai prinsip desain pesan dalam proses pembelajaran. Penelitan ini merupakan penelitian pengembangan suatu produk yang dilakukan dan diarahkan untuk menghasilkan 
suatu produk berupa media pembelajaran interaktif menggunakan simulasi animasi pada matakuliah chasis otomotif untuk mahasiswa Program Studi Pendidikan Teknik Otomotif Jurusan Teknik Mesin Fakultas Teknik Universitas Negeri Medan yang memprogramkan matakuliah chasis otomotif, yang dimaksudkan untuk meningkatkan efektifitas proses pembelajaran maupun kompetensi mahasiswa. Oleh sebab itu proses penelitian ini dilakukan dengan langkalangkah; (1) studi pendahuluan, (2) kemudian mendesain media pembelajaran, (3) melakukan validasi produk dan melakukan revisi dan penyempurnaan berdasarkan analisis data validasi dari ahli materi, ahli desain pembelajaran dan ahli media, (4) yang dilanjutkan dengan uji coba perorangan, uji coba kelompok kecil, dan uji coba lapangan, sehingga dihasilkan media pembelajaran yang layak digunakan sesuai dengan karakteristik bidang studi dan mahasiswa sebagai pengguna.

Beberapa kegunaan dan manfaat dalam penggunaan media pembelajaran interaktif menggunakan simulasi animasi pada matakuliah chasis otomotif sebagai berikut: (1) materi mudah dipahami karena konsep yang disajikan direncanakan untuk mempermudah mahasiswa dan sistematis, (2) media pembelajaran interaktif menggunakan simulasi animasi memberi kesempatan mahasiswa untuk belajar sesuai dengan kecepatan masingmasing individu, (3) belajar lebih cepat dan menarik sehingga tidak menimbulkan kebosanan karena dilengkapi dengan gambargambar dan animasi serta soal latihan yang bervariasi, dan (4) adanya kesempatan dalam menjawab soal pada waktu tes jika jawaban dianggap salah dengan tujuan agar mahasiswa dapat memahami materi yang telah dipelajari, serta (5) media pembelajaran interaktif ini juga dapat digunakan sebagai alternatif media pembelajaran secara konvensional maupun individual. Nilai persentase rata-rata kualitas materi pembelajaran aspek kemudahan memahami pembelajaran pada uji coba perorangan, kelompok kecil, dan lapangan sebesar $91,11 \%$. Sedangkan nilai persentase rata-rata kualitas teknis/tampilan aspek interaksi pada uji coba perorangan, kelompok kecil, dan lapangan sebesar 90,74\%.

Penggunaan media pembelajaran interaktif menggunakan simulasi animasi ini memungkinkan mahasiswa untuk lebih mudah memahami materi sistem kemudi karena dari media pembelajaran ini memungkinkan mahasiswa untuk berinteraksi langsung, memiliki gambar-gambar, animasi, sound background dan soal yang hasilnya dapat dilihat langsung oleh mahasiswa sebagai pebelajar. Dengan demikian setiap mahasiswa tidak kesulitan lagi dalam membayangkan dalam hal proses kerja suatu sistem yang ada pada materi karena didalam media ini telah dijelaskan secara detail. Selain itu, media pembalajaran ini sangat praktis, karena media ini dapat dibawa oleh mahasiswa dan dapat dipelajari dirumah karena media pembelajaran interaktif tersebut dalam bentuk flash. Media pembelajaran ini juga dapat menguji kemampuan dan pemahaman mahasiswa secara langsung melalui tes atau soal-soal latihan pilihan berganda yang memiliki durasi waktu dan kunci jawaban yang benar, sehingga mahasiswa dapat mengetahui kesalahan yang telah dilakukan dalam mengerjakan soal latihan tersebut. Media pembelajaran interaktif juga dilengkapi dengan rangkuman yang dapat membantu mahasiswa memperoleh ringkasan materi kuliah yang dipaparkan.

$$
\text { Pembelajaran dengan media }
$$

pembelajara interaktif menggunakan simulasi animasi juga memungkinkan para dosen pengampuh matakuliah bebas melakukan interaksi dengan mahasiswa sehingga pembelajaran tersebut bersifat interaktif yang membuat pembelajaran terfokus pada informasi yang sedang dipelajari. Hal ini berbeda dengan pembelajaran tanpa menggunakan media pembelajaran interaktif, dimana mahasiswa tidak berinteraksi langsung pada sumber informasi dan pembelajaran didominasi oleh dosen yang menyajikan informasi secara linier atau satu arah, selain itu dalam pembelajaran matakuliah chasis otomotif sangat dituntut mahasiswa untuk mampu mengenal komponen, mengetahui fungsi komponen, serta memahami prinsip kerja dari sistem yang ada. Hal tersebut tentunya akan cukup menyulitkan dan membuat perkuliahan menjadi kurang menarik. Tanpa media pembelajaran interaktif menggunakan simulasi animasi mahasiswa mendapatkan sumber informasi hanya dari dosen pengampuh matakuliah yang bersangkutan dengan materimateri yang ada pada buku. Pembelajaran tanpa menggunakan media interaktif menempatkan dosen menggunakan kontrol pembelajaran dengan aktif, sementara mahasiswa relatif pasif menerima dan 
mengikuti apa yang disampaikan dosen. Dosen menyampaikan materi secara terstruktur dengan harapan materi kuliah yang disampaikan dapat dikuasai dengan baik dengan terfokus kepada kemampuan akademik.

\section{PENUTUP}

Berdasarkan data yang diperoleh dan dengan merujuk pada rumusan tujuan serta pembahasan hasil penelitian pengembangan media pembelajaran interaktif menggunakan simulasi animasi yang diuraikan sebelumnya, maka dapat ditarik kesimpulan sebagai berikut :

1. Media pembelajaran interaktif yang dikembangkan pada penelitian ini layak untuk digunakan sebagai media pembelajaran pada matakuliah chasis otomotif untuk mahasiswa program studi Pendidikan Teknik Otomotif Jurusan Teknik Mesin Fakultas Teknik Universitas Negeri Medan. Persentase rata-rata sebesar 90,65\% , nilai 5 pada skala Likert dan berada pada kriteria "sangat baik".

2. Hasil validasi ahli materi terhadap media pembelajaran interaktif menggunakan simulasi animasi pada matakuliah chasis otomotif yang dikembangkan dengan menggunakan beberapa program dan Macromedia Flash Professioanl 8.0 secara keseluruhan termasuk dalam kategori "Sangat Baik", dengan rincian ; (a) kualitas materi pembelajaran dinilai sangat baik dengan persentase rata-rata sebesar $95,00 \%$, (b) kualitas strategi pembelajaran dinilai sangat baik dengan persentase rata-rata sebesar $92,00 \%$, dan (c) kualitas sistem penyampaian pembelajaran dinilai sangat baik dengan persentase rata-rata sebesar $90,00 \%$.

3. Hasil validasi ahli desain pembelajaran terhadap media pembelajaran interaktif menggunakan simulasi animasi pada matakuliah chasis otomotif yang dikembangkan dengan menggunakan beberapa program dan Macromedia Flash Professional 8.0 menunjukkan bahwa secara keseluruhan termasuk dalam kategori "Sangat Baik", dengan rincian; (a) kualitas desain pembelajaran dinilai sangat baik dengan persentase rata-rata $87,50 \%$, (b) kualitas desain informasi dinilai sangat baik dengan persentase rata-rata sebesar $88,80 \%$, (c) kualitas desain interaksi dinilai sangat baik dengan persentase rata-rata sebesar 90,00\%, (d) kualitas desain presentasi dinilai sangat baik dengan persentase rata-rata sebesar $83,30 \%$.

4. Hasil validasi ahli media terhadap media pembelajaran interaktif menggunakan simulasi animasi pada matakuliah chasis otomotif yang dikembangkan dengan beberapa program dan Macromedia Flash Professioanal 8.0 menunjukkan bahwa secara keseluruhan termasuk dalam kategori "sangat baik", dengan rincian; (a) pemrograman dinilai sangat baik dengan persentase rata-rata sebesar $91,30 \%$, (b) kualitas teknis/tampilan dinilai sangat baik dengan persentase rata-rata sebesar $92,00 \%$.

5. Menurut tanggapan mahasiswa program studi Pendidikan Teknik Otomotif Jurusan Teknik Medin Fakultas Teknik Universitas Negeri Medan pada uji coba perorangan dinyatakan bahwa media pembelajaran interaktif yang dikembangkan dengan beberapa program dan Macromedia Flash Professional 8.0 termasuk kategori "sangat baik" dimana aspek materi pembelajaran dinilai dengan persentase rata-rata sebesar $89,17 \%$ dan kualitas teknis tampilan sebesar $88,57 \%$.

6. Menurut tanggapan mahasiswa program studi Pendidikan Teknik Otomotif Jurusan Teknik Medin Fakultas Teknik Universitas Negeri Medan pada uji coba kelompok kecil dinyatakan bahwa media pembelajaran interaktif yang dikembangkan dengan beberapa program dan Macromedia Flash Professional 8.0 termasuk kategori sangat baik dimana aspek materi pembelajaran dinilai dengan persentase rata-rata sebesar 90,28\% dan kualitas teknis tampilan sebesar $90,48 \%$.

7. Menurut tanggapan mahasiswa program studi Pendidikan Teknik Otomotif Jurusan Teknik Medin Fakultas Teknik Universitas Negeri Medan pada uji coba lapangan dinyatakan bahwa media pembelajaran interaktif yang dikembangkan dengan beberapa program dan Macromedia Flash Professional 8.0 termasuk kategori sangat baik dimana aspek materi pembelajaran dinilai dengan persentase rata-rata sebesar 93,17\% dan kualitas teknis tampilan sebesar $93,30 \%$.

\section{DAFTAR PUSTAKA}


Arikunto, Suharsimi. (2006). Prosedur Penelitian Suatu Pendekatan Praktik. Jakarta : Rineka Cipta.

Budiningsih, Asri . (2003). Desain pesan pembelajaran. Yogyakarta : Fakultas Ilmu Pendidikan Universitas Negeri Yogyakarta.

Borg, W. \&V Gall, M.D. (1983). Educational research. An introduction (4nd ed). New York \& London: Longman.

Dick, W. dan Cary, L. (2005). The systematic design of instruction. United States of America: Scott Foresman and Company.

Djamarah dan Zein. 2006. Strategi Belajar Mengajar. Jakarta: Rineka Cipta.

Gagne, Robert M and Briggs, Leslie J. (1979). Principles of Instructional Design (2nd $E d$.). New York: Holt, Rinehart and Winston.

Hacbart, Steven. (1996). The educational technology hand book. New Jersey. Educational Technology Publications, Inc.

Heinich, Robert, et. Al. (1996) Instructional media and technologies for learning (5th ed). New Jersey : A Simon \& Schuster Company Engelewood Cliffs.

Hornby. A.S. 1985. Oxford Advanced Learner's Dictionary of Current English, Oxford USA: Oxford University Pres.

Hakim, Lukmanul. (2003). Teknik jitu menguasai macromedia flash MX 2004. Jakarta: Elex Media Komputindo.

Kemp. (1994). Design effective instruction. New York: Macmillan College Publishing Company.

Mukminan. (2004). Desain pembelajaran. Yogyakarta: Program Pascasarjana Universitas Negeri Yogyakarta.

Mansur, Muslich. 2008. KTSP. Pembelajaran Berbasis Kompetensi dan Kontekstual. Jakarta : Bumi Aksara.

Nolker,. Helmut and Schoenfeldt, Eberhard. 1988. berufsbildung: Unterricht, Curriculum, Platung ( Pendidikan Kejuruan: Pengajaran, Kurikulum, Perencanaan). Penerjemah: Agus Setiadi. Jakarta: P.T. Gramedia.
Rob Phillips, (1997). Interaktive multimedia. Boston : Kogan

Romiszowski. (1988). The selection and use of instructional media. United States: Nichols Publishing.

Russel, JD. (1974). Modular instruction. Amerika: Burgess Publishing Company.

Sagala, Syaiful. 2005. Konsep dan Makna Pembelajaran. Bandung: Alfabeta.

Sato, G.T. dan Hartanto, N.S. 2004. Menggambar Mesin Menurut standar ISO. Jakarta: PT Pradnya paramita.

Seells dan Richey. 1996). Instructional technology (Mahasiswa S2 IKIP Malang Terjemahan). IKIP Malang.

Slameto, 2003. Belajar dan faktor-faktor yang mempengaruhinya, Jakarta : Rhineka Cipta.

Sleeman, Philip. J. (1979). Instructional media and technology. New York: Long man Inc.

Suparman M, Atwi. (2001). Desain instruksional. Pusat antar Universitas untuk Peningkatan dan Pengembangan Aktivitas Instruksional. Jakarta: Direktorat Jenderal Pendidkan Tinggi, Departemen Pendidikan Tinggi. (2001).

Sudjana, Nana. 2004. Penilaian Hasil Proses Belajar Mengajar. Bandung : Rosdakarya.

Sudjana. 2005. Media Pengajaran. Bandung : Sinar Baru Algensindo.

Sugiyono. 2003. Metode Penelitian Administrasi. Bandung : CV. Alfabeta.

Sukardjo. (2000). Kecenderungan baru (trend) teknologi pembelajaran kimia. Makalah disajikan pada Seminar Regional di Jurdik Kimia UNY.

Waddington , D.J. (1984). Teaching school chemistry. Paris : Unesco.

Waldopo. (2002). Penelitian dan pengembangan, pendekatan dalam mengembangkan produk-produk di bidang pendidikan pembelajaran. Jurnal Teknodik. Desember 2002. Jakarta: Pustekkom. 